\title{
Triglyme-Based Electrolyte for Sodium-Ion and Sodium-Sulfur Batteries
}

\author{
Daniele Di Lecce ${ }^{\mathrm{a}}$, Luca Minnetti ${ }^{\mathrm{a}}$, Daniele Polidoro ${ }^{\mathrm{a}}$, Vittorio Marangon $^{\mathrm{a}}$, and Jusef Hassoun ${ }^{\mathrm{a} \mathrm{b}^{*}}$ \\ ${ }^{a}$ Department of Chemical and Pharmaceutical Sciences, University of Ferrara, Via Fossato di Mortara, \\ 17, 44121, Ferrara, Italy. \\ , sodium-alloying electrodes are attracting ${ }^{\mathrm{b}}$ National Interuniversity Consortium of Materials Science \\ and Technology (INSTM) University of Ferrara Research Unit, University of Ferrara, Via Fossato di \\ Mortara, 17, 44121, Ferrara, Italy. \\ *Corresponding authors: jusef.hassoun@unife.it
}

\section{Keywords}

Triethylene glycol dimethyl ether; TREGDME; $\mathrm{NaCF}_{3} \mathrm{SO}_{3}$; sodium-ion; sodium-sulfur battery

\begin{abstract}
Herein we investigate a lowly flammable electrolyte formed by dissolving sodium trifuoromethansulfonate $\left(\mathrm{NaCF}_{3} \mathrm{SO}_{3}\right)$ salt in triethylene glycol dimethyl ether (TREGDME) solvent as suitable medium for application in Na-ion and Na-S cells. The study, performed by using various electrochemical techniques, including impedance spectroscopy, voltammetry, and galvanostatic cycling, indicates for the solution high ionic conductivity and sodium transference number $\left(\mathrm{t}^{+}\right)$, suitable stability window, very low electrode/electrolyte interphase resistance and sodium stripping/deposition overvoltage. Direct exposition to flame reveals the remarkable safety of the solution due to missing fire evolution under the adopted experimental setup. The solution is further investigated in sodium cells using various electrodes, i.e., mesocarbon microbeads (MCMB), tin-carbon (Sn-C), and sulfur-multiwalled carbon nanotubes (S-MWCNTs). The results show suitable cycling performances, with stable capacity ranging from $90 \mathrm{mAh} \mathrm{g}^{-1}$ for MCMB to $140 \mathrm{mAh} \mathrm{g}^{-1}$ for Sn-C, and to $250 \mathrm{mAh} \mathrm{g}^{-1}$ for S-MWCNTs,
\end{abstract}


thus suggesting the electrolyte as promising candidate for application in sustainable sodium-ion and sodium-sulfur batteries.

\section{Introduction}

Sodium is one of the most abundant elements in the earth crust, hence it attracts an increasing interest as material for energy storage alternative to lithium.[1] Despite higher weight and less negative redox potential with respect to lithium, i.e., $23 \mathrm{~g} \mathrm{~mol}^{-1}, 7 \mathrm{~g} \mathrm{~mol}^{-1},-2.7 \mathrm{~V}$ and $-3.0 \mathrm{~V} v$ s. SHE, respectively, sodium is less geo-localized and more available; hence it may lower the economic impact in view of large scale production of battery [2]. However, this reactive alkali metal suffers from typical safety issues ascribed to dendrite formation during the electrochemical process, short circuits as well as possible thermal runway and venting during battery operation $[3,4]$. Therefore, suitable electrolyte media are of key importance for allowing the proper operation of sodium cell, both using the metal anode and employing the Na-ion configuration [5]. Carbonate-based electrolytes, such as ethylene carbonate (EC) and diethyl carbonate (DEC) containing either $\mathrm{NaPF}_{6}$ or $\mathrm{NaClO}_{4}$ salts, have been widely used as sodium conducting media in battery [5]. However, the notable tendency to form dendrites in sodium cell using these solutions suggested the employment of fluoroethylene carbonate (FEC) [6-8] or vinylene carbonate (VC) [9] as film forming additives for achieving improved performances. Recent reports investigated solid and composite electrolytes with the aim of decreasing the safety hazards of sodium cells [10, 11]. Electrolyte based on ionic liquids and poly(ethylene oxide) have shown suitable thermal and electrochemical characteristics for application in both lithium and sodium batteries with enhanced safety content [12-16]. Among possible electrolytes, solutions using end-capped poly-ether (i.e., glyme) solvents and various salts, including sodium trifuoromethansulfonate $\left(\mathrm{NaCF}_{3} \mathrm{SO}_{3}\right)$ and sodium bis(trifluoromethanesulfonyl)imide (NaTFSI), revealed very promising characteristics in terms of conductivity, sodium transport number and electrochemical stability [5, 12, 17-28]. Furthermore, the relatively low flammability these solutions, particularly for the high molecular weight glyme, appeared 
as an important additional bonus for enhancing the battery safety level [29-31]. A room-temperature rechargeable sodium-ion battery was formed by coupling the layered $\mathrm{P} 2-\mathrm{Na} 0.7 \mathrm{CoO} 2$ cathode with the graphite anode in an electrolyte formed by $\mathrm{NaClO}_{4}$ salt in tetraethylene glycol dimethyl (TEGDME) [32]. This rocking chair cell, operating though sodium intercalation/de-intercalation processes within the cathode and anode layers, has shown suitable electrode/electrolyte interphase, and excellent performance in terms of cycle life, efficiency, and power capability [32]. A rechargeable sodium-oxygen cell has been reported to efficiently operate at room temperature employing a cathode formed by multiwalled carbon nanotubes (MWCNTs) cast on a gas diffusion layer in a TEGDME-NaCF3 $\mathrm{SO}_{3}$ electrolyte solution [33]. The above $\mathrm{Na} / \mathrm{O}_{2}$ cell has shown charge-discharge polarization as low as $400 \mathrm{mV}$, a capacity of $500 \mathrm{mAh}$ $\mathrm{g}^{-1}$ and an energy efficiency of $83 \%$ for several cycles [33]. Diethylene glycol dimethyl ether (DEGDME) dissolving $\mathrm{NaCF}_{3} \mathrm{SO}_{3}$ has been used as the electrolyte in a room temperature sodium-sulfur cell using a S-MWCNTs composite, revealing average working voltage of about $1.8 \mathrm{~V}$ and a specific capacity of the order of $500 \mathrm{mAh} \mathrm{g}^{-1}$ [17], while a sodium-ion cell combining nanostructured $\mathrm{Sn}-\mathrm{C}$ anode and hollow carbon spheres-sulfur (HCS-S) cathode in a TEGDME- $\mathrm{NaCF}_{3} \mathrm{SO}_{3}$ electrolyte revealed remarkable capacity of $550 \mathrm{mAh} \mathrm{g}^{-1}$ and theoretical energy density of $550 \mathrm{Wh} \mathrm{kg}^{-1}$ [34]. These encouraging results have suggested the use of glyme-based electrolytes as the preferred electrolyte media for a series of very attracting energy storage systems based on sodium, including $\mathrm{Na}-\mathrm{ion}, \mathrm{Na} / \mathrm{S}$ and $\mathrm{Na} / \mathrm{O}_{2}$ batteries.

Therefore, in this work we investigate a solution formed by dissolving $\mathrm{NaCF}_{3} \mathrm{SO}_{3}$ in triethylene glycol dimethyl ether (TREGDME) as suitable electrolyte for sodium battery. The solution is studied by various electrochemical techniques in order to determine its ionic conductivity, transport characteristics, electrochemical and chemical stability. The electrolyte is also employed in sodium cell using electrode materials designed for Na-ion application, such as tin-carbon ( $\mathrm{Sn}-\mathrm{C}$ ) and graphitic mesocarbon microbeads (MCMB). Furthermore, the solution is used in a room temperature $\mathrm{Na} / \mathrm{S}$ cell with a composite 
cathode combining multi-walled carbon nanotubes and sulfur. The results suggest the applicability of the electrolyte in efficient and sustainable sodium battery.

\section{Results and discussion}

Safety has a key role in determining the suitability of the electrolyte for sodium battery. Therefore, we have performed a test consisting of direct exposure of the TREGDME- $\mathrm{NaCF}_{3} \mathrm{SO}_{3}$ electrolyte to a butane flame under ambient conditions (photographic images in Fig. 1) [29]. The test reveals that the sample doesn't undergo ignition upon $30 \mathrm{~s}$ of exposure (Fig. 1A, B) as the fire evolution over the solution is missing after the test (Fig. 1C). Despite further flammability tests in different experimental conditions are certainly required to evaluate the safety content of the TREGDME- $\mathrm{NaCF}_{3} \mathrm{SO}_{3}$ solution [35], we can consider the electrolyte a promising candidate for a possible employment in battery. The lower flammability of the TREGDME- $\mathrm{NaCF}_{3} \mathrm{SO}_{3}$ electrolyte compared to the conventional carbonate-based ones, already observed for analogue solutions used in lithium battery [30], may be likely attributed to low vapor pressure of the glyme solvents which further decreases by raising the chain length, thus favoring the safety content of the electrolyte [36]. This trend indicates long chain glymes, such as polyethylene glycol dimethyl ether (PEGDME), as the most suitable candidate for achieving the maximum safety [37]. However, further parameters depending on the chain length determine the suitability of the electrolyte for battery application; among them the most important are the ion transport ability, the chemical and the electrochemical stability [38].

\section{Figure 1}

Therefore, ion transport properties and electrochemical characteristics of the TREGDME$\mathrm{NaCF}_{3} \mathrm{SO}_{3}$ electrolyte have been studied and reported in Figure 2. Panel A of Fig. 2 reports the Nyquist plots of electrochemical impedance spectroscopy (EIS) performed on a symmetrical blocking cell using a Teflon ring as the separator to fix the cell constant in inset (see the experimental section for further 
details) and the related Arrhenius plot with linear fit. EIS reveals the typical response attributed to the electrolyte resistance $\left(R_{e}\right)$ and the double layer capacitance $\left(\mathrm{C}_{\mathrm{dl}}\right.$, see Fig. 2A inset) and suggests ionic conductivity ranging from $3 \times 10^{-3} \mathrm{~S} \mathrm{~cm}^{-1}$ at the room temperature to $5 \times 10^{-3} \mathrm{~S} \mathrm{~cm}^{-1}$ at about $80{ }^{\circ} \mathrm{C}$. These values are in agreement with previous reports on liquid, glyme-based electrolytes for both lithium and sodium batteries $[17,39,40]$, and are slightly lower than those attributed to conventional, flammable, alkyl-carbonate-based electrolytes [41], thereby suggesting the TREGDME- $\mathrm{NaCF}_{3} \mathrm{SO}_{3}$ solution as adequate electrolyte for low-resistance sodium cells. In addition, the small value of slope obtained by linear fitting of the curve (inset of Fig. 2A) indicates a limited activation energy for the ion transport likely reflected into a fast $\mathrm{Na}^{+}$diffusion into the electrolyte, which may possibly lead to high rate capability in non-blocking electrode cell [42]. The sodium transference number $\left(\mathrm{t}^{+}\right)$, i.e., a parameter ranging from 0 to 1 indicating the ration of the charge transported by $\mathrm{Na}^{+}$ions, is an important characteristic of the electrolyte solution since it strongly influences the interphase resistance during the electrochemical process and the associated charge transfer features; in fact, high values of $\mathrm{t}^{+}$likely lead to small resistance and fast electrochemical process at the electrode/electrolyte interlayer [5]. Fig. 2B shows the chronoamperometric profiles and EIS Nyquist plots (inset) before and after polarization of two symmetrical sodium cells employed to evaluate the $\mathrm{Na}^{+}$transference number $\left(\mathrm{t}^{+}\right)$by the Bruce-VincentEvans equation (1) [43].

$$
t^{+}=\frac{I_{S S}\left(\Delta V-I_{0} R_{0}\right)}{I_{0}\left(\Delta V-I_{S S} R_{S S}\right)}
$$

where $\mathrm{I}_{0} \mathrm{e}$ Iss are the initial and the steady state-currents, $\Delta \mathrm{V}$ is the applied signal, $\mathrm{R}_{0}$ e $\mathrm{R}_{s s}$ are the electrode/electrolyte interphase resistances before and after polarization. Both cells exhibit similar response in terms of current and impedance features. Although slight differences due to cell assembly are observed, both experiments provide a sodium transference number of 0.72 , thus further confirming the reliability of the method developed by Evans and co-workers [43]. This value is considered very 
suitable for efficient application in low resistance sodium cells [5]. Indeed, the lithium transference number has been measured and previously reported by using the above electrochemical technique for various lithium and sodium salts in several solvents. TEGDME-NaCF $3 \mathrm{SO}_{3}$ with 4:1 molar ratio has shown a $\mathrm{t}^{+}$number of 0.76 [34], while the lithium transfer number was of 0.8 for the lithium solutions of various concentrations using the same solvent, that is, TEGDME: $\mathrm{LiCF}_{3} \mathrm{SO}_{3}$ with the $4: 1$ molar ratio [44] and a TEGDME:LiCF $3 \mathrm{SO}_{3}$ solution with $1 \mathrm{~kg}: 1 \mathrm{~mol}$ ratio [45]. However, the evaluation of $\mathrm{Na}^{+}$ transference number actually depends on the technique employed for determination, as revealed by comparison with previous works in which we have used NMR and electrochemical methods. In this respect, it is worth mentioning that the cation transference number determined by NMR (i.e., the apparent transport number) is generally lower than that determined by the electrochemical method since the former takes into account the self-diffusion coefficients of the ion species, while the latter provides an estimation of the net alkali ion motion upon application of electric field.

Further important characteristics of the electrolyte solution are the electrochemical and chemical stability of the $\mathrm{Na}$ /electrolyte interphase, which are herein determined by galvanostatic stripping deposition tests (Fig. 2C) and EIS measurements throughout 30 days of storage (Fig. 2C, inset), respectively, performed on a sodium symmetrical cell. Fig. $2 \mathrm{C}$ reveals that the electrolyte has a charge/discharge polarization as low as $4 \mathrm{mV}$, which slightly increases to about $5 \mathrm{mV}$ and stabilizes by the ongoing of the test due to a modest raise and consolidation of the solid electrolyte interphase (SEI) film as the electrochemical process of Na occurs [17]. Similar trend is evidenced by the EIS test of the symmetrical cell (Fig. 2C inset), which shows very low impedance (about $1 \Omega$ ) at the initial stages of the measurement, and a still very low value of about $3 \Omega$ after 30 days of storage as the SEI is fully formed [17]. Such an excellent trend is generally reflected into an optimal electrolyte performance in sodium cell, characterized by long cycle life and remarkable stability [34]. The electrochemical stability window of the electrolyte is determined in sodium cells using Super P carbon as the working electrode by cyclic 
voltammetry $(\mathrm{CV})$ in the cathodic region and linear scan voltammetry (LSV) in the anodic region (Fig. 2D). The figure evidences typical cathodic profile (blue curve), characterized by an irreversible peak at about $0.8 \mathrm{~V} v s . \mathrm{Na}^{+} / \mathrm{Na}$ associated with the reductive decomposition of the electrolyte and formation of a protective SEI at the electrode surface, as well as by a remarkably reproducible CV trend during the subsequent cycles, in which only reversible (de)insertion and deposition/dissolution of sodium over the SP carbon electrode at about 0.9 and $0 \mathrm{~V} v s . \mathrm{Na}^{+} / \mathrm{Na}$, respectively, are observed [17]. Concerning the anodic scan (red curve in Fig. 2D), a small increase of the current may be observed at about $3 \mathrm{~V} v s$. $\mathrm{Na}^{+} / \mathrm{Na}$, most likely due to a partial oxidation of the electrolyte, while the full oxidative decomposition may be detected only at about $4 \mathrm{~V} v s$. $\mathrm{Na}^{+} / \mathrm{Na}$. It is noteworthy that undesired electrolyte decomposition processes are generally mitigated by the addition to the electrolyte solution of film forming additives [5], such as $\mathrm{NaNO}_{3}$ [17], which is a procedure still under investigation in our laboratory and will be reported in future works. We would mention however that the materials studied in this paper as the working electrodes in sodium cell, i.e., MCMB, Sn-C, and S-MWCNTs, operate within the above determined stability windows of the TREGDME- $\mathrm{NaCF}_{3} \mathrm{SO}_{3}$ electrolyte, i.e., within 0 and $3 \mathrm{~V} v s . \mathrm{Na}^{+} / \mathrm{Na}$. Based on the low bulk and sodium/electrolyte interphase resistances of TREGDME- $\mathrm{NaCF}_{3} \mathrm{SO}_{3}$ at room temperature, we have performed the following tests in sodium cells at $25{ }^{\circ} \mathrm{C}$.

\section{Figure 2}

The electrolyte is characterized in combination with a MCMB electrode for application in sodium-ion cell. Figure 3 reports the voltage profile (A) and galvanostatic cycling trend with Coulombic efficiency (B) of a Na/TREGDME-NaCF $3 \mathrm{SO}_{3} / \mathrm{MCMB}$ cell at a current of $\mathrm{C} / 8\left(1 \mathrm{C}=372 \mathrm{~mA} \mathrm{~g}^{-1}\right)$. During the first discharge, the $\mathrm{Na} / \mathrm{TREGDME}-\mathrm{NaCF}_{3} \mathrm{SO}_{3} / \mathrm{MCMB}$ cell shows a voltage signature characterized by the presence of an irreversible plateau around $1 \mathrm{~V}$ followed by irreversible processes below $1 \mathrm{~V}$, leading to a specific capacity of about $210 \mathrm{mAh} \mathrm{g}^{-1}$ (see Fig. 3A). The subsequent charge/discharge 
cycles of Fig. 3A reveal reversible processes between 1.4 and $0 \mathrm{~V}$ with a capacity of about $80 \mathrm{mAh} \mathrm{g}^{-1}$, due co-intercalation into the MCMB graphite planes of $\mathrm{Na}^{+}$-electrolyte complexes, as indeed observed in previous works using a graphite electrode in sodium cell with a glyme-based electrolyte [32]. Thus, Fig. 3 indicates an irreversible capacity at the $1^{\text {st }}$ cycle of about $130 \mathrm{mAh} \mathrm{g}^{-1}$, which may be ascribed to the well-known electrolyte reduction and SEI formation occurring at low voltage [46]. It is worth mentioning that a stable SEI with suitable composition, thickness and porosity is typically required to employ electrodes working below $1 \mathrm{~V} v s . \mathrm{Na}^{+} / \mathrm{Na}$ in ether-based electrolytes [47]. Furthermore, Fig. 3B evidences very stable capacity of about $85 \mathrm{mAh} \mathrm{g}^{-1}$ during cycles, and a Coulombic efficiency approaching $100 \%$, except for the first cycle which has an efficiency of $90 \%$ due to the SEI film formation and consolidation at the electrode/electrolyte interphase [48]. It is worth mentioning that unfavorable mismatch between graphite structure and $\mathrm{Na}^{+}$ions in alkyl carbonate solutions generally avoids efficient operation of this material as the anode in sodium-ion battery using conventional electrolytes. Instead, solvent co-intercalation in electrolytes based on glyme have proven to ensure suitable cycling stability, high efficiency and reversible capacity of the order of $100 \mathrm{mAh} \mathrm{g}^{-1}$ through a typical voltage signature reflecting the staged redox behavior [22]. On the other hand, the smaller dimension of naked $\mathrm{Li}^{+}$ions leads to a relatively higher intercalation degree into graphite materials in standard carbonate-based electrolytes, with maximum reversible capacity of $372 \mathrm{mAh} \mathrm{g}^{-1}$ through a voltage profile mostly centered at $0.3 \mathrm{~V}$ [49]. However, both lithium and sodium cells exhibit comparable electrochemical behavior due to solvent co-intercalation in glyme-based solutions [50]. Despite a relatively low capacity, various advantages, including remarkable safety, stability, and expected low cost account for the use of the MCMB electrode in a sodium-ion configuration for sustainable energy storage [3].

Figure 3 
Among the various anode materials, sodium-alloying electrodes attract increasing interest due to the high expected capacity associated with the exchange of more than one alkali metal per formula unit during the electrochemical process [51]. Nanocomposite materials based on antimony (Sb), tin ( $\mathrm{Sn}$ ), and germanium $(\mathrm{Ge})$ are promising candidates as anodes for sodium-ion cells, as they benefit from the exchange of more than $2 \mathrm{Na}^{+}$ions during the alloying process, thus leading to theoretical capacities higher than $500 \mathrm{mAh} \mathrm{g}^{-1}[3,52,53]$. The use of nanocomposite morphologies is an effective approach to mitigate possible deterioration of electrodes reacting via alloying and conversion mechanisms, since it can mitigate the huge volume change associated with the electrochemical reaction, thereby enhancing the cycling stability [54-56]. Therefore, we have studied herein the TREGDME-NaCF $3 \mathrm{SO}_{3}$ electrolyte with an Sn-C nanostructured electrode characterized by an $\mathrm{Sn}$ to $\mathrm{C}$ ratio of 35:65 by weight [57, 58]. The composite material, prepared via a sol-gel method optimized in our laboratories involving polymerization of resorcinol to form a hydrogel embedding organometallic tin, followed by pyrolysis [57, 59], has been widely studied so far in terms of structure, morphology, composition, and electrochemical properties both in lithium and sodium batteries of various configurations as well as with liquid, polymer and ionic liquid electrolytes [34, 39, 60-65], demonstrating versatile characteristics suitable for possible application. The $\mathrm{Sn}$ to $\mathrm{C}$ ratio leads to a reversible capacity in lithium cell of about $400 \mathrm{mAh} \mathrm{g}^{-1}$, based on the specific capacity of $\mathrm{Sn}$ and amorphous carbon, i.e., 993 and $100 \mathrm{mAh} \mathrm{g}^{-1}$, respectively [58]. Figure 4 shows the voltage profile (A) and cycling trend with Coulombic efficiency (B) of the Na/TREGDME$\mathrm{NaCF}_{3} \mathrm{SO}_{3} / \mathrm{Sn}-\mathrm{C}$ cell studied at a current of $50 \mathrm{~mA} \mathrm{~g}^{-1}$. The cell exhibits a first discharge characterized by a huge irreversible capacity, i.e., $280 \mathrm{mAh} \mathrm{g}^{-1}$, reasonably attributed to concomitant electrolyte reduction, SEI film formation, and electrode structural reorganization [65]. After the $1^{\text {st }}$ cycle, the electrochemical process of Sn-C in sodium cell evolves through the typical sloped voltage curve centered at about $0.5 \mathrm{~V}$, which may be mostly ascribed to the $\mathrm{Na}-\mathrm{Sn}$ alloying reaction with a reversible capacity of about $130 \mathrm{mAh} \mathrm{g}^{-1}$ (see Fig. 4A) [65]. The low capacity with respect to pure tin may be partially 
attributed to the electrode composition, which comprises a Sn content of $35 \mathrm{wt} . \%$ within an amorphous carbon matrix.[62] We have previously shown that Sn-C delivers a significantly lower reversible capacity in sodium cells with both alkyl carbonate- and glyme-based electrolytes, that is, within the range from 120 to $180 \mathrm{mAh} \mathrm{g}^{-1}[34,65]$. Despite the sodium (de)alloying process has been clearly demonstrated by ex situ XRD [64, 65], exact quantification of the capacity attributed to $\mathrm{Sn}$ and $\mathrm{C}$ has been not carried out yet. Galvanostic cycling of a carbon-based electrode prepared in similar condition might elucidate this point in further publications focusing on the anode. However, based on the lithium cell performances and the voltage profile in sodium cell of Sn-C [34, 58, 65], as well as the electrochemical study of a similar Sb-C material prepared through comparable approach [51], we may estimate a large contribution of the Na-alloying reaction. In particular, since the electrode delivers in sodium cell about $30 \%$ of the capacity observed in lithium cell, we may reasonably expect a maximum contribution of insertion into the amorphous carbon of about $20 \mathrm{mAh} \mathrm{g}^{-1}$. The nanostructured nature of tin within the composite electrode leads to a characteristic sloping profile that differs from that of bulk materials using the same metal [66]. The cycling trend of Fig. 4B indicates a remarkably prolonged stability of the process which proceeds with an efficiency approaching $100 \%$ after few cycles characterized by lower values due to the above mentioned SEI film formation and structural reorganization of the nanocomposite [65]. Therefore, elevated stability, low operating voltage and a relatively high delivered capacity suggest the Sn-C material herein studied as the preferred electrode for application in sodium-ion cell.

\section{Figure 4}

The sulfur electrode is characterized by high specific capacity in sodium-cell due to its electrochemical process involving multiple-ion exchange [67]. In this work we have selected a SMWCNTs material studied in an our previous paper as the working electrode for a sodium battery operating at the room temperature [17]. Figure 5 shows the voltage profile (A), the cycling trend and the 
Coulombic efficiency (B) of a Na/TREGDME- $\mathrm{NaCF}_{3} \mathrm{SO}_{3} / \mathrm{S}-\mathrm{MWCNTs}$ cell studied at a current of $\mathrm{C} / 20$ $\left(1 \mathrm{C}=1675 \mathrm{~mA} \mathrm{~g}^{-1}\right)$.

The first discharge of the cell (Fig. 5A) is characterized by various voltage plateaus which may be divided into three main groups, thereby suggesting a different reaction mechanism compared to the one widely accepted for lithium-sulfur batteries. The attribution of each plateau to a specific phenomenon occurring in the cell is not unambiguous, since various voltage fingerprints and corresponding reaction mechanisms have been reported so far for similar Na/S systems [17, 24-26, 68]. Further measurements by both ex situ and in situ techniques might elucidate the reaction products formed upon electrochemical process. However, the work herein reported aims to demonstrate the suitability of the TREGDME$\mathrm{NaCF}_{3} \mathrm{SO}_{3}$ electrolyte for various sodium-ion battery systems based on insertion, alloying, and conversion electrodes. The voltage curve here observed is consistent with literature studies on sodiumsulfur batteries [24], which have revealed the reversible multistep conversion reaction of sulfur into longchain and short-chain sodium polysulfides by electrochemical measurements, X-ray photoelectron and UV/Vis spectroscopy. Accordingly, we may attribute the first group of reactions, ranging from 2.1 to 1.8 $\mathrm{V}$, to the formation of long-chain polysulfides, the second one, occurring at constant voltage of about 1.8 $\mathrm{V}$, to the formation of polysulfides with intermediate-length chain, and the third one, characterized by a profile with rather constant slope from 1.8 to $0.4 \mathrm{~V}$, to the formation of short-chain polysulfides along with possible $\mathrm{Na}^{+}$insertion into the MWCNTs $[17,24,68]$. Despite a full understanding of the conversion reaction mechanism is beyond the scope of our work, it is worth mentioning that the electrochemical behavior of Na-S batteries in terms of reversible capacity and working voltage may be strongly affected by both cathode characteristics and cell configuration $[25,26]$. The subsequent charge evolves according to two, rather constant, plateaus at about $1.8 \mathrm{~V}$ and $2.2 \mathrm{~V}$, and leads to the reverse oxidation of the polysulfides likely to sulfur and sodium, with a capacity approaching the one obtained during discharge, i.e., about $500 \mathrm{mAh} \mathrm{g}^{-1}$. However, the second and third cycles reveal a remarkable decrease of the 
delivered capacity accompanied by a reduction of the efficiency, as most likely due to a process involving polysulfide dissolution from the electrode into the electrolyte and precipitation at the anode side, with a significant loss of the active material and resistance increase [69]. Ex situ analyses of sodium-sulfur cells employing glyme-based electrolyte revealed large polysulfide dissolution throughout discharge and charge, which depended on the molar concentration of sulfur [69]. Apparently, the proposed electrolyte does not mitigate neither the polysulfide dissolution nor the polysulfide shuttle, thereby leading to fast capacity fading and large irreversible capacity. Based on the literature on lithium sulfur batteries [70], we reasonably expect that the use of SEI film-forming additives, such as $\mathrm{NaNO}_{3}$, might address the reaction of the dissolved polysulfides at the anode side. However, recent reports have evidenced possible adverse effects of $\mathrm{NaNO}_{3}$ on the stability of the sodium metal anode in polysulfide-containing, glymebased electrolytes [71]. Further studies on the use of $\mathrm{NaNO}_{3}$ in glyme-based electrolytes for sodiumsulfur batteries might elucidate this point.

In a recent report we have investigated the chemical-physical and electrochemical properties of a diglyme-based electrolyte for a sodium battery employing S-MWCNTs cathode. The related results have shown reversible cell operation within the wide voltage range from 0.5 to $2.1 \mathrm{~V}$, although limited to a few cycles, thereby suggesting the possible suitability of the electrolyte once the issues leading to the capacity fading are addressed [17]. Such a wide voltage range allows the evaluation of the SMWCNTs/electrolyte interface behavior aimed to preliminary study of the electrolyte applicability in $\mathrm{Na} / \mathrm{S}$ systems. We have herein investigated a similar solution belonging to the glymes family, by using comparable experimental conditions in order to assess possible effects of the solvent chain length on the electrochemical behavior. Thus, the electrolyte composition slightly influences the cycling response, since the cell using diglyme electrolyte solution shows slightly higher capacity with respect to the one herein reported using the triglyme, as reasonably attributed to the increase of chain length [17]. 
The deterioration process is further evidenced by the cycling trend of the cell reported in Fig. 5B, which shows the decay of the specific capacity to about $150 \mathrm{mAh} \mathrm{g}^{-1}$ after 10 charge/discharge cycles. In order to further shed light on the detrimental phenomena affecting the electrode stability, we have performed an EIS study of a Na/TREGDME-NaCF $3 \mathrm{SO}_{3} / \mathrm{S}-\mathrm{MWCNT}$ cell cycled by voltammetry within the potential range from 0.5 and $2.1 \mathrm{~V}$. Panels $\mathrm{C}$ and D of Fig. 5 report the related voltammetry profiles for three cycles and the Nyquist plots of EIS carried out at the open circuit voltage (OCV) and after each cycle. In agreement with the voltage profiles of panel A and the literature [69], Fig. 5C shows two cathodic peaks at 1.6 and $2.2 \mathrm{~V}$ as well as two weak current signals at 1.9 and $0.8 \mathrm{~V}$, which reflect the multi-step reaction of sulfur with sodium. These processes are partially reversed upon charge through an anodic peak at about $2.0 \mathrm{~V}$. The profiles partially overlap during the subsequent cycles, being characterized by cathodic processes mainly at 1.6 and $0.8 \mathrm{~V}$, and an anodic peak at $2.0 \mathrm{~V}$. According to the galvanostatic cycling results (see panel A and B of Fig. 5), cyclic voltammetry reveals a decrease of the peak intensity by cycling, thereby suggesting worsening kinetics at electrode/electrolyte interphase. This trend is confirmed by EIS, which indicates an electrode/electrolyte interphase resistance as low as $10 \Omega$ at the OCV, as revealed by Fig. 5D inset, remarkably increasing after three cycles to about $130 \Omega$ (see Fig. 5D).

Therefore, we have cast the S-MWCNTs material on a carbon-cloth support (i.e., a gas diffusion layer, GDL) instead of the conventional aluminum support previously used in order to improve the sodium cell stability. Such an improvement by changing the current collector has been observed in recent reports on lithium-sulfur batteries [72-74] and attributed to the microporous texture of the carbon-cloth, leading to an optimal electric contact with the active material, as well as to its favorable chemical composition and wetting ability [75]. Indeed, Fig. 5E compares the cycling trends at C/20 of two sodium cells using the TREGDME- $\mathrm{NaCF}_{3} \mathrm{SO}_{3}$ electrolyte and the S-MWCNTs working electrode cast on either conventional Al or GDL supports. After a first cycle evolving at about $500 \mathrm{mAh}^{-1}$, the cell using the 
sulfur electrode on GDL reveals a fast drop of the capacity by two cycles and a subsequent rapid increase up to about $250 \mathrm{mAh} \mathrm{g}^{-1}$. This behavior is most likely attributed to partial dissolution, and rapid structural re-organization of the active material at the electrode/electrolyte interface [76]. Furthermore, the charge/discharge test prolonged up to 40 cycles indicates a very stable performance of the electrode using GDL, which still delivers a capacity of about $250 \mathrm{mAh} \mathrm{g}^{-1}$, that is, a remarkably higher value compared to the material coated on Al. The GDL support actually mitigates capacity fading and cell degradation. Sodium ions are expected to (co-)intercalate within carbon cloth below $0.9 \mathrm{~V} v s . \mathrm{Na}^{+} / \mathrm{Na}$, and possible electrolyte decomposition al low voltage promoted by high surface area of the GDL support cannot be excluded. It is worth mentioning that we have limited the discharge to $1.6 \mathrm{~V}$ in order to avoid $\mathrm{Na}^{+}$ insertion into the GDL support. Figure 5F compares the steady-state voltage profiles of Na/S-MWCNTs cells employing either aluminum or carbon cloth. The last cell exhibits a voltage curve attributed to the reversible conversion of sulfur into short-chain sodium polysulfides $[17,24,68]$, while the former cell shows poor electrochemical activity. We have also performed a comparative galvanostatic measurement with a sodium cell using a MWCNTs electrode coated on GDL support, by employing the same cycling conditions of the Na/S-MWCNTs cell (the capacity has been normalized with respect to the MWCNTs mass). The related results, reported in Fig. 5F inset, exclude significant contribution of the MWCNTs and GDL materials, as revealed by capacitive profiles and very low specific capacity values. Thus, the promising results of the Na/S-MWCNTs cell employing the GDL support pave the way for further works aimed at cathode optimization. The addition of $\mathrm{NaNO}_{3}$ to the TREGDME- $\mathrm{NaCF}_{3} \mathrm{SO}_{3}$ solution might be considered in further works aimed to mitigate the irreversible capacity of the cell employing the carbon cloth (see Figure 5F) [17]. Considering the observed capacity value, an average working voltage of about 1.7 V, and the sulfur content (see the Experimental section), we may estimate a theoretical energy density with respect to the sulfur mass of about $425 \mathrm{Wh} \mathrm{kg}^{-1}$, leading a practical value of $140 \mathrm{Wh} \mathrm{kg}^{-1}$ roughly considering a correction factor of $1 / 3$ which takes into account the weight of electrolyte, anode, and 
inactive components of the cell, which are values well suitable for sustainable energy storage applications [77]. However, it is worth mentioning that laboratory cells usually employ an excess of electrolyte which may affect the actual energy density.

\section{Figure 5}

\section{Conclusions}

The study of the TREGDME- $\mathrm{NaCF}_{3} \mathrm{SO}_{3}$ solution reported in this work evidenced several characteristics well adequate for the use of the electrolyte in sodium-cell, including an expected high safety content due to relatively low flammability, an ionic conductivity ranging from $10^{-3}$ to $10^{-2} \mathrm{~S} \mathrm{~cm}^{-1}$, depending on the temperature, and Na-transference number higher than 0.7. In addition, the electrolyte has shown a remarkable chemical and electrochemical stability of the $\mathrm{Na}$ /electrolyte interface, with maximum impedance value limited to $3 \Omega$, and Na-stripping/deposition polarization as low as $5 \mathrm{mV}$. Furthermore, the electrolyte revealed an excellent cathodic stability, well suitable for Na-ion cell, while a limited anodic stability reasonably increasing by the use of SEI film-forming additives such as $\mathrm{NaNO}_{3}$, which was however beyond of the scope of the present work. The study of sodium cells using either MCMB and $\mathrm{Sn}-\mathrm{C}$ electrodes, which are materials designed for $\mathrm{Na}$-ion application, revealed good performances, in particular in terms of cycling stability. The Na/MCMB cell has shown a specific capacity of about 90 $\mathrm{mAh} \mathrm{g}^{-1}$ and an average voltage of $0.8 \mathrm{~V}$, while the $\mathrm{Na} / \mathrm{Sn}-\mathrm{C}$ one has delivered about $140 \mathrm{mAh} \mathrm{g}^{-1}$ at 0.5 V. A room-temperature sodium-sulfur cell using the TREGDME- $\mathrm{NaCF}_{3} \mathrm{SO}_{3}$ electrolyte in combination with a S-MWCNTs composite electrode cast on a GDL support has revealed a stable capacity of about $250 \mathrm{mAh} \mathrm{g}^{-1}$ and average voltage of $1.7 \mathrm{~V}$, thus leading to an expected practical energy of the order of

$140 \mathrm{Wh} \mathrm{kg}^{-1}$. Despite needing further optimization in terms of anodic stability, the results reported herein suggest the TREGDME- $\mathrm{NaCF}_{3} \mathrm{SO}_{3}$ solution as a promising electrolyte for sustainable and safe sodiumion and sodium-sulfur batteries. 


\section{Experimental}

The TREGDME-NaCF $3 \mathrm{SO}_{3}$ electrolyte was prepared by dissolving sodium trifuoromethansulfonate $\left(\mathrm{NaCF}_{3} \mathrm{SO}_{3}, 98 \%\right.$, Sigma-Aldrich) in triethylene glycol dimethyl ether (TREGDME, anhydrous, $\mathrm{CH}_{3} \mathrm{O}\left(\mathrm{CH}_{2} \mathrm{CH}_{2} \mathrm{O}\right)_{3} \mathrm{CH}_{3}$, Sigma-Aldrich) in the $1 \mathrm{~mol} / 1 \mathrm{~kg}$ ratio, respectively. The TREGDME$\mathrm{NaCF}_{3} \mathrm{SO}_{3}$ solution is liquid according to the melting point of TREGDME $\left(T_{m}=-40{ }^{\circ} \mathrm{C}\right)$. Both electrolyte components were dried before use. $\mathrm{NaCF}_{3} \mathrm{SO}_{3}$ was heated at $120^{\circ} \mathrm{C}$ under vacuum for 3 days, while TREGDME was dehydrated under dry molecular sieves ( $5 \AA$ A, Sigma-Aldrich) until the 10 ppm water content was reached, as determined by a 899 Karl Fischer Coulometer (Metrohm). TREGDME drying, water titration and electrolyte preparation were carried out in an Ar-filled glovebox (MBraun, $\mathrm{O}_{2}$ and $\mathrm{H}_{2} \mathrm{O}$ content below $1 \mathrm{ppm}$ ). The flammability of the TREGDME- $\mathrm{NaCF}_{3} \mathrm{SO}_{3}$ solution was evaluated through exposure to a butane flame for $30 \mathrm{~s}$.

Electrode slurries were prepared by mixing through an agate mortar the active material, a polymer binder (PVDF 6020, Solvay), and a conductive carbon (Super P, Timcal) using the weight proportion of 80:10:10 in 1-methyl-2-pyrrolidinone (NMP, anhydrous, Sigma-Aldrich). Either mesocarbon microbeads (MCMB, Osaka) [78], or a tin-carbon (Sn-C) composite [57], or a sulfur-multiwalled carbon nanotubes composite (S-MWCNTs, 60:40 w/w) [79] were employed as the electrode active materials. The slurries were casted by doctor blade on either copper (thickness of $25 \mu \mathrm{m}$, MTI Corporation, for MCMB and Sn-C), or aluminum (thickness of $15 \mu \mathrm{m}$, MTI Corporation, for S-MWCNTs) or gas diffusion layer (GDL ELAT LT1400, for S-MWCNTs) foils, which were dried for $3 \mathrm{~h}$ on a hot plate at $70{ }^{\circ} \mathrm{C}$, cut into $14 \mathrm{~mm}$ disks, and heated overnight at either $110{ }^{\circ} \mathrm{C}(\mathrm{MCMB}, \mathrm{Sn}-\mathrm{C})$ or $40{ }^{\circ} \mathrm{C}(\mathrm{S}-$ MWCNTs) under vacuum. The final active material loading of the electrodes were 2.3, 3.0, 0.9, and 2.5 $\mathrm{mg} \mathrm{cm} \mathrm{cm}^{-2}$ for MCMB, Sn-C, S-MWCNTs over Al, and S-MWCNTs over GDL, respectively. Carboncoated $\mathrm{Al}$ and $\mathrm{Cu}$ electrodes were prepared by the doctor blade casting procedure above reported using Super P carbon and PVDF binder in the 80:20 weight ratio, cut into $10 \mathrm{~mm}$ disks and dried overnight at 
$110{ }^{\circ} \mathrm{C}$ under vacuum. Sodium-metal electrode disks with diameter of either $10 \mathrm{~mm}$ or $14 \mathrm{~mm}$ were prepared from sodium cubes (Sigma-Aldrich) by rolling and pressing.

2032 coin-cells (MTI Corporation) and three-electrodes T-type cells were assembled in an Arfilled glovebox (MBraun, $\mathrm{O}_{2}$ and $\mathrm{H}_{2} \mathrm{O}$ content below $1 \mathrm{ppm}$ ), by using sodium metal as the counter and reference electrodes and a Whatman ${ }^{\circledR}$ GF/D glass fiber separator soaked by the TREGDME- $\mathrm{NaCF}_{3} \mathrm{SO}_{3}$ solution. Electrodes having diameter of 10 and $14 \mathrm{~mm}$ were employed for preparing T-type cells and coin-cells, respectively.

The ionic conductivity of the TREGDME- $\mathrm{NaCF}_{3} \mathrm{SO}_{3}$ solution was determined by electrochemical impedance spectroscopy (EIS) on a symmetrical blocking cell using stainless steel (SS) electrodes and a Teflon ring as the separator to fix the cell constant to $4.0 \times 10^{-2} \mathrm{~cm}^{-1}$. EIS was performed by applying an alternate voltage signal with amplitude of $10 \mathrm{mV}$ within the $500 \mathrm{kHz}-10 \mathrm{~Hz}$ frequency range.

The lithium transference number $\left(\mathrm{t}^{+}\right)$of the TREGDME- $\mathrm{NaCF}_{3} \mathrm{SO}_{3}$ electrolyte solution was evaluated by the method developed by Evans et al. [43]. Chronoamperometry and EIS measurements were carried out on a two $\mathrm{Na} / \mathrm{Na}$ symmetrical coin-cells using a Whatman ${ }^{\circledR} \mathrm{GF} / \mathrm{D}$ glass fiber separator soaked by the electrolyte solution. Chronoamperometry was performed by applying to the cell a voltage of $10 \mathrm{mV}$ for 90 min, while impedance spectra were recorded by employing an alternate voltage signal with amplitude of $10 \mathrm{mV}$ within the $100 \mathrm{kHz}-0.1 \mathrm{~Hz}$ frequency range.

The electrochemical stability window of the TREGDME- $\mathrm{NaCF}_{3} \mathrm{SO}_{3}$ solution was evaluated by cyclic voltammetry $(\mathrm{CV})$ in the cathodic range and linear sweep voltammetry (LSV) in the anodic range on three-electrode T-type cells using Super $\mathrm{P}$ carbon electrodes on either $\mathrm{Cu}$ or $\mathrm{Al}$ substrates, respectively, as the working electrode. All the voltammetry experiments were carried out by using a scan rate of 0.1 $\mathrm{mV} \mathrm{s}^{-1}$. The lithium/electrolyte interphase resistance was measured by EIS on symmetrical $\mathrm{Na} / \mathrm{Na}$ coincells throughout 30 days, by applying an alternate voltage signal of $10 \mathrm{mV}$ amplitude in the $100 \mathrm{kHz}-$ $0.1 \mathrm{~Hz}$ frequency range. 
Galvanostatic sodium stripping/deposition tests were carried out by applying $0.1 \mathrm{~mA} \mathrm{~cm}^{-2}$ for $1 \mathrm{~h}$ of charge/discharge to a $\mathrm{Na} / \mathrm{Na}$ symmetrical coin-cell.

Galvanostatic cycling tests were performed on sodium coin-cells using the TREGDME- $\mathrm{NaCF}_{3} \mathrm{SO}_{3}$ electrolyte and either MCMB, or Sn-C, or S-MWCNTs over Al, or S-MWCNTs over GDL. The $\mathrm{Na} / \mathrm{TREGDME}-\mathrm{NaCF}_{3} \mathrm{SO}_{3} / \mathrm{MCMB}$ cell was cycled at a current rate of $\mathrm{C} / 8\left(1 \mathrm{C}=372 \mathrm{~mA} \mathrm{~g}^{-1}\right)$ within the $0-2 \mathrm{~V}$ voltage range; the $\mathrm{Na} / \mathrm{TREGDME}-\mathrm{NaCF}_{3} \mathrm{SO}_{3} / \mathrm{Sn}-\mathrm{C}$ cell was cycled at a current of $50 \mathrm{~mA} \mathrm{~g}^{-1}$ within the $0-2 \mathrm{~V}$ voltage range; both the $\mathrm{Na} / \mathrm{TREGDME}-\mathrm{NaCF}_{3} \mathrm{SO}_{3} / \mathrm{S}-\mathrm{MWCNTs}$ cells using $\mathrm{Al}$ and GDL supports were cycled at a current rate of $\mathrm{C} / 20\left(1 \mathrm{C}=1675 \mathrm{~mA} \mathrm{~g}^{-1}\right)$ within the voltage ranges of 0.4 $-2.1 \mathrm{~V}$ and $1.6-2.1 \mathrm{~V}$, respectively. A comparative sodium cell was assembled by using the TREGDME-NaCF $3 \mathrm{SO}_{3}$ electrolyte and MWCNTs over GDL as working electrode, and cell tested by employing the same experimental conditions of the Na/S-MWCNTs (GDL) cell.

Cyclic voltammetry (CV) of a three-electrode T-type sodium cell using Na metal as the counter and the reference electrode was performed using the TREGDME-NaCF $3 \mathrm{SO}_{3}$ electrolyte and S-MWCNTs coated

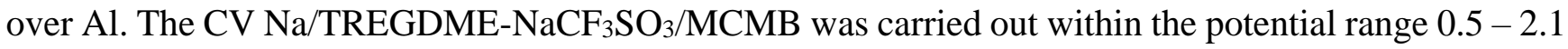
$\mathrm{V} v s \mathrm{Na} / \mathrm{Na}^{+}$using a scan rate of $0.1 \mathrm{mV} \mathrm{s}^{-1}$. EIS measurements of the above cell were performed at the open circuit voltage (OCV) and after each voltammetry cycle within $100 \mathrm{kHz}-0.1 \mathrm{~Hz}$ using AC signal amplitude of $10 \mathrm{mV}$.

EIS, CV, and LSV were performed though a VersaSTAT MC Princeton Applied Research (PAR, AMETEK) instrument, while the galvanostatic measurements were performed through a MACCOR Series 4000 battery test system. All the electrochemical measurements, except for the ionic conductivity ones, were performed at room temperature $\left(25^{\circ} \mathrm{C}\right)$.

\section{Acknowledgements}


The work was founded by the grant "Fondo di Ateneo per la Ricerca Locale (FAR) 2017", University of Ferrara, and performed within the collaboration project "Accordo di Collaborazione Quadro 2015" between the University of Ferrara (Department of Chemical and Pharmaceutical Sciences) and the Sapienza University of Rome (Department of Chemistry).

\section{References}

1. Kundu D, Talaie E, Duffort V, Nazar LF (2015) The emerging chemistry of sodium ion batteries for electrochemical energy storage. Angew Chemie - Int Ed 54:3432-3448. https://doi.org/10.1002/anie.201410376

2. Hwang J-Y, Myung S-T, Sun Y-K (2017) Sodium-ion batteries: present and future. Chem Soc Rev 46:3529-3614. https://doi.org/10.1039/C6CS00776G

3. Hasa I, Hassoun J, Passerini S (2017) Nanostructured Na-ion and Li-ion anodes for battery application: A comparative overview. Nano Res 10:3942-3969. https://doi.org/10.1007/s12274017-1513-7

4. Wang Q, Ping P, Zhao X, Chu G, Sun J, Chen C (2012) Thermal runaway caused fire and explosion of lithium ion battery. J Power Sources 208:210-224. https://doi.org/10.1016/j.jpowsour.2012.02.038

5. Che H, Chen S, Xie Y, Wang H, Amine K, Liao X-Z, Ma Z-F (2017) Electrolyte design strategies and research progress for room-temperature sodium-ion batteries. Energy Environ Sci 10:10751101. https://doi.org/10.1039/C7EE00524E

6. Komaba S, Ishikawa T, Yabuuchi N, Murata W, Ito A, Ohsawa Y (2011) Fluorinated ethylene carbonate as electrolyte additive for rechargeable $\mathrm{Na}$ batteries. ACS Appl Mater Interfaces 3:4165-4168. https://doi.org/10.1021/am200973k

7. Islam M, Jeong M-G, Hwang J-Y, Oh I-H, Sun Y-K, Jung H-G (2017) Self-assembled nickel- 
cobalt oxide microspheres from rods with enhanced electrochemical performance for sodium ion battery. Electrochim Acta 258:220-227. https://doi.org/10.1016/j.electacta.2017.10.114

8. Ming J, Ming H, Yang W, Kwak W-J, Park J-B, Zheng J, Sun Y-K (2015) A sustainable ironbased sodium ion battery of porous carbon- $\mathrm{Fe}_{3} \mathrm{O}_{4} / \mathrm{Na}_{2} \mathrm{FeP}_{2} \mathrm{O}_{7}$ with high performance. RSC Adv 5:8793-8800. https://doi.org/10.1039/C4RA14733B

9. Zhang X, Fan C, Xiao P, Han S (2016) Effect of vinylene carbonate on electrochemical performance and surface chemistry of hard carbon electrodes in lithium ion cells operated at $\begin{array}{llll}\text { different } & \text { temperatures. } & \text { Electrochim }\end{array}$ https://doi.org/10.1016/j.electacta.2016.10.149

10. Song S, Duong HM, Korsunsky AM, Hu N, Lu L (2016) $\mathrm{A} \mathrm{Na}^{+}$superionic conductor for roomtemperature sodium batteries. Sci Rep 6:32330. https://doi.org/10.1038/srep32330

11. Song S, Kotobuki M, Zheng F, Xu C, Savilov SV, Hu N, Lu L, Wang Y, Li WDZ (2017) A hybrid polymer/oxide/ionic-liquid solid electrolyte for Na-metal batteries. J Mater Chem A 5:6424-6431. https://doi.org/10.1039/C6TA11165C

12. Serra Moreno J, Armand M, Berman MB, Greenbaum SG, Scrosati B, Panero S (2014) Composite PEOn:NaTFSI polymer electrolyte: Preparation, thermal and electrochemical characterization. J Power Sources 248:695-702. https://doi.org/10.1016/j.jpowsour.2013.09.137

13. Yang Q, Zhang Z, Sun X-G, Hu Y-S, Xing H, Dai S (2018) Ionic liquids and derived materials for lithium and sodium batteries. Chem Soc Rev 47:2020-2064. https://doi.org/10.1039/C7CS00464H

14. Park C-W, Ryu H-S, Kim K-W, Ahn J-H, Lee J-Y, Ahn H-J (2007) Discharge properties of allsolid sodium-sulfur battery using poly (ethylene oxide) electrolyte. J Power Sources 165:450454. https://doi.org/10.1016/j.jpowsour.2006.11.083

15. Di Lecce D, Sharova V, Jeong S, Moretti A, Passerini S (2018) A multiple electrolyte concept for 
lithium-metal batteries. Solid State Ionics 316:66-74. https://doi.org/10.1016/j.ssi.2017.12.012

16. Agostini M, Ulissi U, Di Lecce D, Ahiara Y, Ito S, Hassoun J (2015) A lithium-ion battery based on an ionic liquid electrolyte, tin-narbon nanostructured anode, and $\mathrm{Li}_{2} \mathrm{O}-\mathrm{ZrO}_{2}$-coated $\mathrm{Li}\left[\mathrm{Ni} 0.8 \mathrm{Co} 0.15 \mathrm{Al}_{0.05} \mathrm{O}_{2} \quad\right.$ cathode. $\quad$ Energy $\quad$ Technol 3:632-637. https://doi.org/10.1002/ente.201402226

17. Carbone L, Munoz S, Gobet M, Devany M, Greenbaum S, Hassoun J (2017) Characteristics of glyme electrolytes for sodium battery: nuclear magnetic resonance and electrochemical study. Electrochim Acta 231:223-229. https://doi.org/10.1016/j.electacta.2017.02.007

18. Kim H, Hong J, Park Y-U, Kim J, Hwang I, Kang K (2015) Sodium storage behavior in natural graphite using ether-based electrolyte systems. Adv Funct Mater 25:534-541. https://doi.org/10.1002/adfm.201402984

19. Dutta PK, Mitra S (2017) Efficient sodium storage: Experimental study of anode with additivefree ether-based electrolyte system. J Power Sources 349:152-162. https://doi.org/10.1016/j.jpowsour.2017.03.031

20. Das SK, Jache B, Lahon H, Bender CL, Janek J, Adelhelm P (2016) Graphene mediated improved sodium storage in nanocrystalline anatase $\mathrm{TiO}_{2}$ for sodium ion batteries with ether electrolyte. Chem Commun 52:1428-1431. https://doi.org/10.1039/C5CC09656A

21. Zhu Y-E, Yang L, Zhou X, Li F, Wei J, Zhou Z (2017) Boosting the rate capability of hard carbon with an ether-based electrolyte for sodium ion batteries. J Mater Chem A 5:9528-9532. https://doi.org/10.1039/C7TA02515G

22. Jache B, Binder JO, Abe T, Adelhelm P (2016) A comparative study on the impact of different glymes and their derivatives as electrolyte solvents for graphite co-intercalation electrodes in lithium-ion and sodium-ion batteries. Phys Chem Chem Phys 18:14299-14316. https://doi.org/10.1039/C6CP00651E 
23. Guo C, Zhang K, Zhao Q, Peia L, Chen J (2015) High-performance sodium batteries with the 9,10-anthraquinone/CMK-3 cathode and an ether-based electrolyte. Chem Commun 51:1024410247. https://doi.org/10.1039/C5CC02251G

24. Yu X, Manthiram A (2014) Capacity enhancement and discharge mechanisms of roomtemperature sodium-sulfur batteries. ChemElectroChem 1:1275-1280. https://doi.org/10.1002/celc.201402112

25. Ryu H, Kim T, Kim K, Ahn J-H, Nam T, Wang G, Ahn H-J (2011) Discharge reaction mechanism of room-temperature sodium-sulfur battery with tetra ethylene glycol dimethyl ether liquid electrolyte. J Power Sources 196:5186-5190. https://doi.org/10.1016/j.jpowsour.2011.01.109

26. Wei S, Xu S, Agrawral A, Choudhury S, Lu Y, Tu Z, Ma L, Archer LA (2016) A stable roomtemperature sodium-sulfur battery. Nat Commun 7:11722. https://doi.org/10.1038/ncomms11722

27. Li J, Yan D, Lu T, Qin W, Yao Y, Pan L (2017) Significantly improved sodium-ion storage performance of $\mathrm{CuS}$ nanosheets anchored into reduced graphene oxide with ether-based electrolyte. ACS Appl Mater Interfaces 9:2309-2316. https://doi.org/10.1021/acsami.6b12529

28. Zhang J, Wang D-W, Lv W, Zhang S, Liang Q, Zheng D, Kanga F, Yang Q-H (2017) Achieving superb sodium storage performance on carbon anodes through an ether-derived solid electrolyte interphase. Energy Environ Sci 10:370-376. https://doi.org/10.1039/C6EE03367A

29. Benítez A, Di Lecce D, Caballero Á, Morales J, Rodríguez-Castellón E, Hassoun J (2018) Lithium sulfur battery exploiting material design and electrolyte chemistry: 3D graphene framework and diglyme solution. J Power Sources 397:102-112. https://doi.org/10.1016/j.jpowsour.2018.07.002

30. Di Lecce D, Carbone L, Gancitano V, Hassoun J (2016) Rechargeable lithium battery using nonflammable electrolyte based on tetraethylene glycol dimethyl ether and olivine cathodes. J Power Sources 334:146-153. https://doi.org/10.1016/j.jpowsour.2016.09.164

31. Carbone L, Moro PT, Gobet M, Munoz S, Devany M, Greenbaum SG, Hassoun J (2018) Enhanced 
lithium oxygen battery using a glyme electrolyte and carbon nanotubes. ACS Appl Mater Interfaces 10:16367-16375. https://doi.org/10.1021/acsami.7b19544

32. Hasa I, Dou X, Buchholz D, Shao-Horn Y, Hassoun J, Passerini S, Scrosati B (2016) A sodiumion battery exploiting layered oxide cathode, graphite anode and glyme-based electrolyte. J Power Sources 310:26-31. https://doi.org/10.1016/j.jpowsour.2016.01.082

33. Elia GA, Hasa I, Hassoun J (2016) Characterization of a reversible, low-polarization sodiumoxygen battery. Electrochim Acta 191:516-520. https://doi.org/10.1016/j.electacta.2016.01.062

34. Lee D-J, Park J-W, Hasa I, Sun Y-K, Scrosati B, Hassoun J (2013) Alternative materials for sodium ion-sulphur batteries. J Mater Chem A 1:5256. https://doi.org/10.1039/c3ta10241f

35. Hess S, Wohlfahrt-Mehrens M, Wachtler M (2015) Flammability of Li-ion battery electrolytes: flash point and self-extinguishing time measurements. J Electrochem Soc 162:A3084-A3097. https://doi.org/10.1149/2.0121502jes

36. Tobishima S, Morimoto H, Aoki M, Saito Y, Inose T, Fukumoto T, Kuryu T (2004) Glyme-based nonaqueous electrolytes for rechargeable lithium cells. Electrochim Acta 49:979-987. https://doi.org/10.1016/j.electacta.2003.10.009

37. Carbone L, Gobet M, Peng J, et al (2015) Polyethylene glycol dimethyl ether (PEGDME)-based electrolyte for lithium metal battery. J Power Sources 299:460-464. https://doi.org/10.1016/j.jpowsour.2015.08.090

38. Carbone L, Gobet M, Peng J, Devany M, Scrosati B, Greenbaum S, Hassoun J (2015) Comparative study of ether-based electrolytes for application in lithium-sulfur battery. ACS Appl Mater Interfaces 7:13859-13865. https://doi.org/10.1021/acsami.5b02160

39. Di Lecce D, Fasciani C, Scrosati B, Hassoun J (2015) A gel-polymer Sn-C/LiMn0.5Fe ${ }_{0.5} \mathrm{PO}_{4}$ battery using a fluorine-free salt. ACS Appl Mater Interfaces 7:21198-21207. https://doi.org/10.1021/acsami.5b05179 
40. Carbone L, Di Lecce D, Gobet M, Munoz S, Devany M, Greenbaum S, Hassoun S (2017) Relevant features of a triethylene glycol dimethyl ether-based electrolyte for application in lithium battery. ACS Appl Mater Interfaces 9:17085-17095. https://doi.org/10.1021/acsami.7b03235

41. Xu K (2014) Electrolytes and interphases in Li-ion batteries and beyond. Chem Rev 114:1150311618. https://doi.org/10.1021/cr500003w

42. Ratner MA, Shriver DF (1988) Ion transport in solvent-free polymers. Chem Rev 88:109-124. https://doi.org/10.1021/cr00083a006

43. Evans J, Vincent CA, Bruce PG (1987) Electrochemical measurement of transference numbers in polymer electrolytes. Polymer 28:2324-2328. https://doi.org/10.1016/0032-3861(87)90394-6

44. Lee D-J, Agostini M, Park J-W, Sun Y-K, Hassoun J, Scrosati B (2013) Progress in LithiumSulfur Batteries: The effective role of a polysulfide-added electrolyte as buffer to prevent cathode dissolution. ChemSusChem 6:2245-2248. https://doi.org/10.1002/cssc.201300313

45. Elia GA, Park J, Sun Y, Scrosati B, Hassoun J (2014) Role of the lithium salt in the performance of lithium-oxygen batteries: a comparative study. ChemElectroChem 1:47-50. https://doi.org/10.1002/celc.201300160

46. Eshetu GG, Diemant T, Hekmatfar M, Grugeon S, Behm RJ, Laruelle S, Armand M, Passerini S (2019) Impact of the electrolyte salt anion on the solid electrolyte interphase formation in sodium ion batteries. Nano Energy 55:327-340. https://doi.org/10.1016/j.nanoen.2018.10.040

47. Zhang J, Wang D-W, Lv W, Qin L, Niu S, Zhang S, Cao T, Kang F, Yang Q-H (2018) Ethers illume sodium-based battery chemistry: uniqueness, surprise, and challenges. Adv Energy Mater 8:1801361. https://doi.org/10.1002/aenm.201801361

48. Bridel J-S, Grugeon S, Laruelle S, Hassoun J, Reale P, Scrosati B, Tarascon J-M (2010) Decomposition of ethylene carbonate on electrodeposited metal thin film anode. J Power Sources 195:2036-2043. https://doi.org/10.1016/j.jpowsour.2009.10.038 
49. Winter M, Besenhard JO, Spahr ME, Novák P (1998) Insertion electrode materials for rechargeable lithium batteries. Adv Mater 10:725-763. https://doi.org/10.1002/(SICI)15214095(199807)10:10<725::AID-ADMA725>3.0.CO;2-Z

50. Jache B, Adelhelm P (2014) Use of graphite as a highly reversible electrode with superior cycle life for sodium-ion batteries by making use of co-intercalation phenomena. Angew Chemie Int Ed 53:10169-10173. https://doi.org/10.1002/anie.201403734

51. Hasa I, Passerini S, Hassoun J (2015) A rechargeable sodium-ion battery using a nanostructured $\mathrm{Sb}-\mathrm{C}$ anode and P2-type layered Na0.6Ni0.22Fe0.11Mn0.66O2 cathode. RSC Adv 5:48928-48934. https://doi.org/10.1039/C5RA06336A

52. Zhang Z, Zhao J, Wang H, Gong Y, Xu JL (2018) Facile synthesis of Sb/CNT nanocomposite as anode material for sodium-ion batteries. Funct Mater Lett 11:1850004. https://doi.org/10.1142/S1793604718500042

53. Farbod B, Cui K, Kalisvaart WP, Kupsta M, Zahiri B, Kohandehghan A, Lotfabad EM, Li Z, Luber EJ, Mitlin D (2014) Anodes for sodium ion batteries based on tin-germanium-antimony alloys. ACS Nano 8:4415-4429. https://doi.org/10.1021/nn4063598

54. Scrosati B, Hassoun J, Sun Y-K (2011) Lithium-ion batteries. A look into the future. Energy Environ Sci 4:3287. https://doi.org/10.1039/c1ee01388b

55. Fan X-Y, Liu P, Wang S, Han J, Ni K, Gou L, Xu L, Li D, Lin C, Li R (2018) Electrochemical construction and sodium storage performance of three-dimensional porous self-supported $\mathrm{MoS}_{2}$ electrodes. Funct Mater Lett 11:1850050. https://doi.org/10.1142/S1793604718500509

56. Liu J, Dai J, Huang L, Fu B (2018) Flexible and binder-free electrospun $\mathrm{Co}_{3} \mathrm{O}_{4}$ nanoparticles/carbon composite nanofiber mats as negative electrodes for sodium-ion batteries. Funct Mater Lett 11:1850072. https://doi.org/10.1142/S1793604718500728

57. Hassoun J, Derrien G, Panero S, Scrosati B (2008) A nanostructured Sn-C composite lithium 
battery electrode with unique stability and high electrochemical performance. Adv Mater 20:3169-3175. https://doi.org/10.1002/adma.200702928

58. Elia GA, Nobili F, Tossici R, Marassi R, Savoini A, Panero S, Hassoun J (2015) Nanostructured tin-carbon/ $\mathrm{LiNi}_{0.5} \mathrm{Mn}_{1.5} \mathrm{O}_{4}$ lithium-ion battery operating at low temperature. J Power Sources 275:227-233. https://doi.org/10.1016/j.jpowsour.2014.10.144

59. Derrien G, Hassoun J, Panero S, Scrosati B (2007) Nanostructured Sn-C composite as an advanced anode material in high-performance lithium-ion batteries. Adv Mater 19:2336-2340. https://doi.org/10.1002/adma.200700748

60. Di Lecce D, Brutti S, Panero S, Hassoun J (2015) A new Sn-C/LiFe0.1Co0.9PO4 full lithium-ion cell with ionic liquid-based electrolyte. Mater Lett 139:329-332. https://doi.org/10.1016/j.matlet.2014.10.089

61. Lecce D Di, Verrelli R, Hassoun J (2016) New lithium ion batteries exploiting conversion/alloying anode and $\mathrm{LiFe}_{0.25} \mathrm{Mn}_{0.5} \mathrm{Co}_{0.25} \mathrm{PO}_{4}$ olivine cathode. Electrochim Acta 220:384-390. https://doi.org/10.1016/j.electacta.2016.10.067

62. Elia GA, Ulissi U, Jeong S, Passerini S, Hassoun J (2016) Exceptional long-life performance of lithium-ion batteries using ionic liquid-based electrolytes. Energy Environ Sci 9:3210-3220. https://doi.org/10.1039/C6EE01295G

63. Hassoun J, Scrosati B (2010) A high-performance polymer tin sulfur lithium ion battery. Angew Chemie Int Ed 49:2371-2374. https://doi.org/10.1002/anie.200907324

64. Hasa I, Hassoun J, Sun Y-K, Scrosati B (2014) Sodium-ion battery based on an electrochemically converted $\mathrm{NaFePO}_{4}$ cathode and nanostructured tin-carbon anode. ChemPhysChem 15:21522155. https://doi.org/10.1002/cphc.201400088

65. Oh S-M, Myung S-T, Jang M-W, Scrosati B, Hassoun J, Sun Y-K (2013) An advanced sodiumion rechargeable battery based on a tin-carbon anode and a layered oxide framework cathode. Phys 
Chem Chem Phys 15:3827-3833. https://doi.org/10.1039/c3cp00070b

66. Zhang B, Rousse G, Foix D, Dugas R, Dalla Corte DA, Tarascon J-M (2016) Microsized Sn as advanced anodes in glyme-based electrolyte for Na-ion batteries. Adv Mater 28:9824-9830. https://doi.org/10.1002/adma.201603212

67. Lim D-H, Agostini M, Ahn J-H, Matic A (2018) An electrospun nanofiber membrane as gel-based electrolyte for room-temperature sodium-sulfur batteries. Energy Technol 6:1214-1219. https://doi.org/10.1002/ente.201800170

68. Kumar D, Rajouria SK, Kuhar SB, Kanchan DK (2017) Progress and prospects of sodium-sulfur batteries: A review. Solid State Ionics 312:8-16. https://doi.org/10.1016/j.ssi.2017.10.004

69. Kim I, Park J-YJ-W, Kim C, Park J-W, Ahn J-P, Ahn J-H, Kim K-W, Ahn H-J (2016) Sodium polysulfides during charge/discharge of the room-temperature Na/S battery using TEGDME electrolyte. J Electrochem Soc 163:A611-A616. https://doi.org/10.1149/2.0201605jes

70. Carbone L, Greenbaum SG, Hassoun J (2017) Lithium sulfur and lithium oxygen batteries: new frontiers of sustainable energy storage. Sustain Energy Fuels 1:228-247. https://doi.org/10.1039/C6SE00124F

71. Wang H, Wang C, Matios E, Li W (2018) Facile stabilization of the sodium metal anode with additives: unexpected key role of sodium polysulfide and adverse effect of sodium nitrate. Angew Chemie Int Ed 57:7734-7737. https://doi.org/10.1002/anie.201801818

72. Shin HD, Agostini M, Belharouak I, Hassoun J, Sun Y-K (2016) High-power lithium polysulfidecarbon battery. Carbon N Y 96:125-130. https://doi.org/10.1016/j.carbon.2015.09.034

73. Benítez A, Di Lecce D, Elia GA, Caballero Á, Morales J, Hassoun J (2018) A lithium-ion battery using a 3 D-array nanostructured graphene-sulfur cathode and a silicon oxide-based anode. ChemSusChem 11:1512-1520. https://doi.org/10.1002/cssc.201800242

74. Di Lecce D, Marangon V, Benítez A, Caballero Á, Morales J, Rodríguez-Castellón E, Hassoun J 
(2019) High capacity semi-liquid lithium sulfur cells with enhanced reversibility for application in new-generation energy storage systems. J Power Sources 412:575-585. https://doi.org/10.1016/j.jpowsour.2018.11.068

75. Benítez A, Caballero Á, Rodríguez-Castellón E, Morales J, Hassoun J (2018) The role of current collector in enabling the high performance of Li/S battery. ChemistrySelect 3:10371-10377. https://doi.org/10.1002/slct.201802529

76. Carbone L, Peng J, Agostini M, Gobet M, Devany M, Scrosati B, Greenbaum S, Hassoun J (2017) carbon composites for a high-energy lithium-sulfur battey with a glyme-based electrolyte. ChemElectroChem 4:209-215. https://doi.org/10.1002/celc.201600586

77. Di Lecce D, Verrelli R, Hassoun J (2017) Lithium-ion batteries for sustainable energy storage: recent advances towards new cell configurations. Green Chem 19:3442-3467. https://doi.org/10.1039/C7GC01328K

78. Di Lecce D, Verrelli R, Campanella D, Marangon V, Hassoun J (2017) A new CuO- $\mathrm{Fe}_{2} \mathrm{O}_{3}-$ mesocarbon microbeads conversion anode in a high-performance lithium-ion battery with a

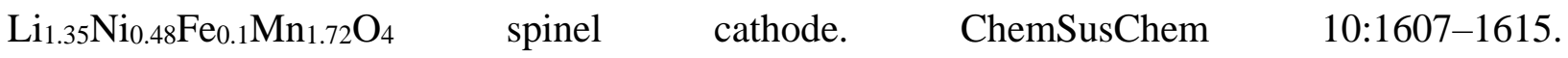
https://doi.org/10.1002/cssc.201601638

79. Carbone L, Coneglian T, Gobet M, Munoz S, Devany M, Greenbaum S, Hassoun J (2018) A simple approach for making a viable, safe, and high-performances lithium-sulfur battery. J Power Sources 377:26-35. https://doi.org/10.1016/j.jpowsour.2017.11.079 


\section{List of figures}

Figure 1. (A-B) Photographic images of the TREGDME-NaCF $3 \mathrm{SO}_{3}$ electrolyte (A) before, (B) during, and $(\mathbf{C})$ after direct exposure to a butane flame for $30 \mathrm{~s}$ under ambient conditions.

Figure 2. (A-D) Ion transport properties and electrochemical characteristics of the TREGDME$\mathrm{NaCF}_{3} \mathrm{SO}_{3}$ electrolyte. (A) Arrhenius plots of the ionic conductivity with corresponding linear fit and Nyquist plots (Inset). Electrolyte resistances for the calculation determined by electrochemical impedance spectroscopy (EIS) within $500 \mathrm{kHz}-10 \mathrm{~Hz}$ on a SS/electrolyte/SS symmetrical cell using AC signal amplitude of $10 \mathrm{mV}$. (B) Chronoamperometric profile and EIS Nyquist plots (inset) before and after polarization of two $\mathrm{Na} /$ electrolyte/ $\mathrm{Na}$ symmetrical cells employed for the determination of $\mathrm{Na}^{+}$ transference number $\left(\mathrm{t}^{+}\right)$by the Bruce-Vincent-Evans equation (1). Chronoamperometry performed by applying to the cell a voltage of $10 \mathrm{mV}$ for $90 \mathrm{~min}$. EIS performed within $100 \mathrm{kHz}-0.1 \mathrm{~Hz}$ using AC signal amplitude of $10 \mathrm{mV}$. (C) Galvanostatic sodium stripping deposition test performed at $0.1 \mathrm{~mA} \mathrm{~cm}^{-2}$ for $1 \mathrm{~h}$ of charge/discharge and interphase resistance evolution during time (inset) determined by electrochemical impedance spectroscopy (EIS) within $100 \mathrm{kHz}-0.1 \mathrm{~Hz}$ with AC signal amplitude of 10 $\mathrm{mV}$ on $\mathrm{Na} /$ electrolyte/Na symmetrical cells. (D) Cyclic voltammetry (CV, cathodic region) and linear scan voltammetry (LSV, anodic region) performed for determining the electrochemical stability window of the electrolyte in sodium cells using Super $\mathrm{P}$ carbon coated on either $\mathrm{Cu}$ or $\mathrm{Al}$ substrates, respectively, as the working electrode. Scan rate: $0.1 \mathrm{mV} \mathrm{s}^{-1}$.

Figure 3. (A-B) Voltage profile (A) and cycling trend with Coulombic efficiency (B) of a $\mathrm{Na} / \mathrm{TREGDME}-\mathrm{NaCF}_{3} \mathrm{SO}_{3} / \mathrm{MCMB}$ cell galvanostatically studied at a current of $\mathrm{C} / 8\left(1 \mathrm{C}=372 \mathrm{~mA} \mathrm{~g}^{-1}\right)$. Voltage limits $0-2 \mathrm{~V}$. Room temperature $\left(25^{\circ} \mathrm{C}\right)$

Figure 4. (A-B) Voltage profile (A) and cycling trend with Coulombic efficiency (B) of a $\mathrm{Na} / \mathrm{TREGDME}-\mathrm{NaCF}_{3} \mathrm{SO}_{3} / \mathrm{Sn}-\mathrm{C}$ cell galvanostatically studied at a current of $50 \mathrm{~mA} \mathrm{~g}$. Voltage limits $0-2$ V. Room temperature $\left(25^{\circ} \mathrm{C}\right)$ 
Figure 5. (A-B) Voltage profile (A) and cycling trend with Coulombic efficiency (B) of a $\mathrm{Na} / \mathrm{TREGDME}-\mathrm{NaCF}_{3} \mathrm{SO}_{3} / \mathrm{S}-\mathrm{MWCNTs}$ cell galvanostatically studied at a current of $\mathrm{C} / 20(1 \mathrm{C}=1675$ $\mathrm{mA} \mathrm{g}^{-1}$ ). (C) Cyclic voltammetry of a $\mathrm{Na} / \mathrm{TREGDME}-\mathrm{NaCF}_{3} \mathrm{SO}_{3} / \mathrm{S}-\mathrm{MWCNTs}$ cell and (D) related Nyquist plots of EIS measurements performed at the OCV and after the $1^{\text {st }}, 2^{\text {nd }}$ and $3^{\text {rd }}$ voltammetry cycles. Potential limits: $0.5-2.1 \mathrm{~V}$ vs $\mathrm{Na}^{+} / \mathrm{Na}$. Scan rate: $0.1 \mathrm{mV} \mathrm{s}^{-1}$. EIS performed within $100 \mathrm{kHz}-$ $0.1 \mathrm{~Hz}$ using AC signal amplitude of $10 \mathrm{mV}$. (E-F) Comparison of cycling trends and (F) voltage profiles of the $25^{\text {th }}$ cycle at $\mathrm{C} / 20$ of two sodium cells using the TREGDME- $\mathrm{NaCF}_{3} \mathrm{SO}_{3}$ electrolyte and the SMWCNTs working electrode cast on conventional Al and gas diffusion layer (GDL) supports. Voltage limits: $0.4-2.5 \mathrm{~V}$ for aluminum, $1.6-2.5 \mathrm{~V}$ for GDL. Capacity limited to $500 \mathrm{mAh} \mathrm{g}^{-1}$. Inset of panel F: voltage profiles of a comparative sodium cell using the TREGDME- $\mathrm{NaCF}_{3} \mathrm{SO}_{3}$ electrolyte and MWCNTs over GDL as working electrode; cell tested by employing the same experimental conditions of the Na/S-MWCNTs (GDL) cell. Room temperature $\left(25^{\circ} \mathrm{C}\right)$. 


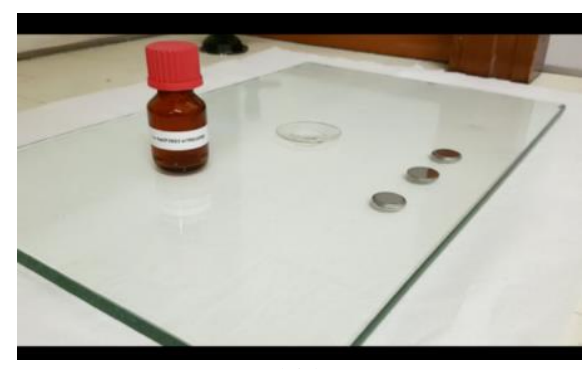

(A)

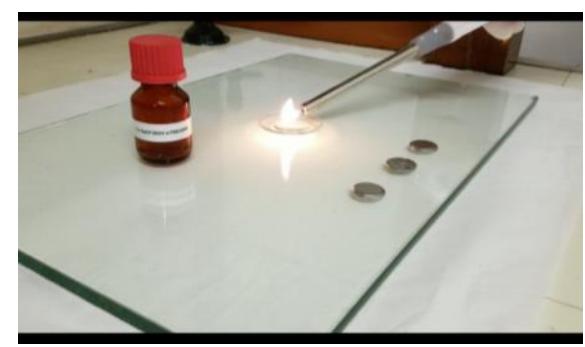

(B)

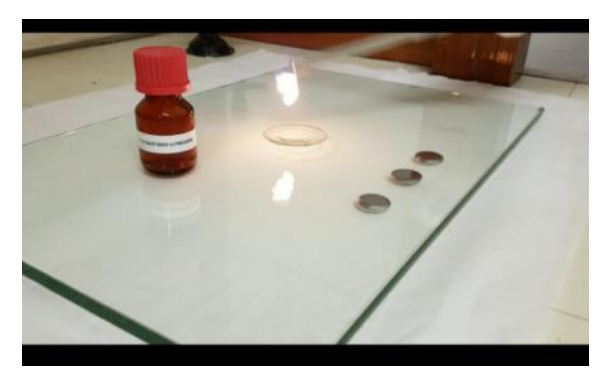

(C)

Figure 1 

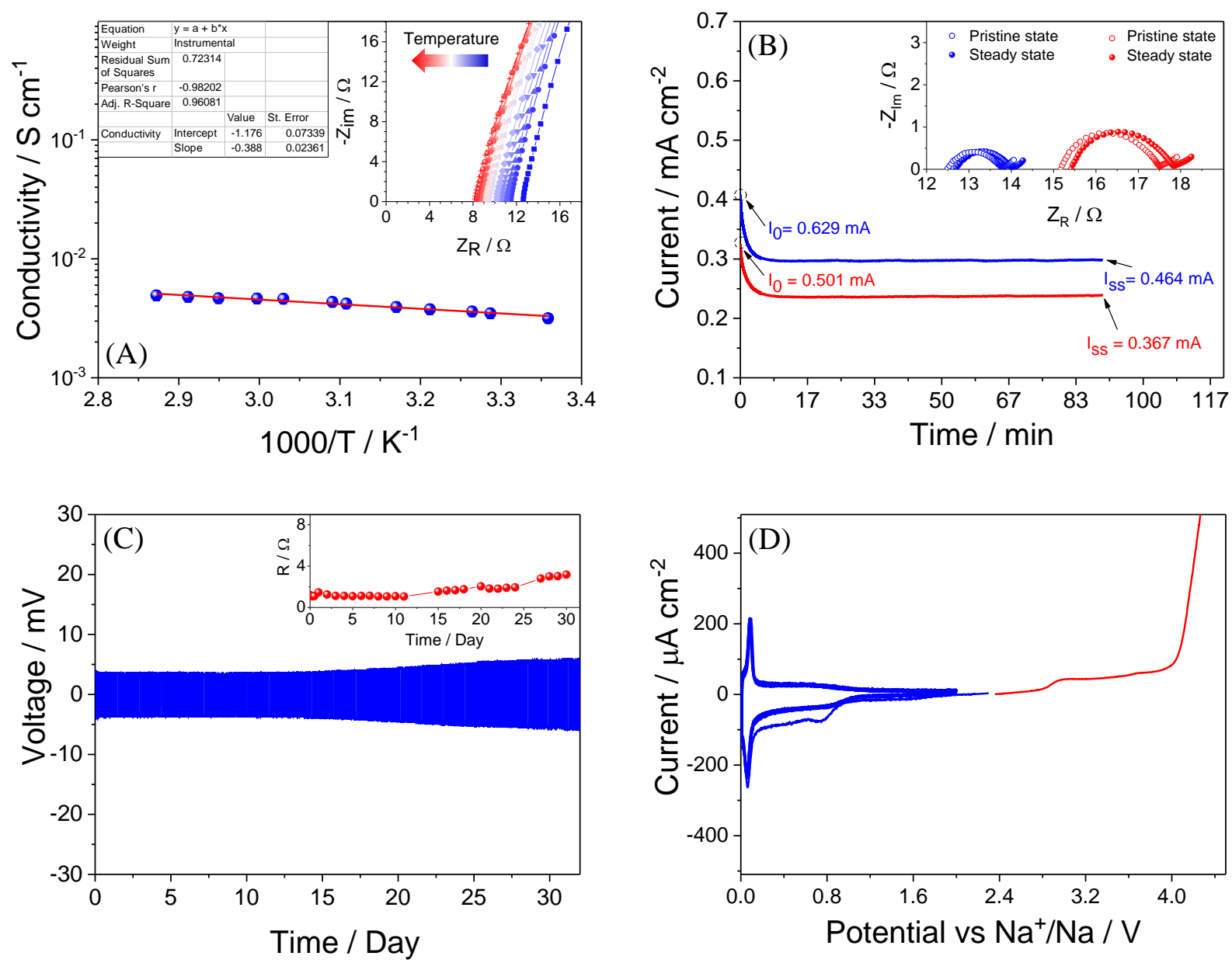

Figure 2 

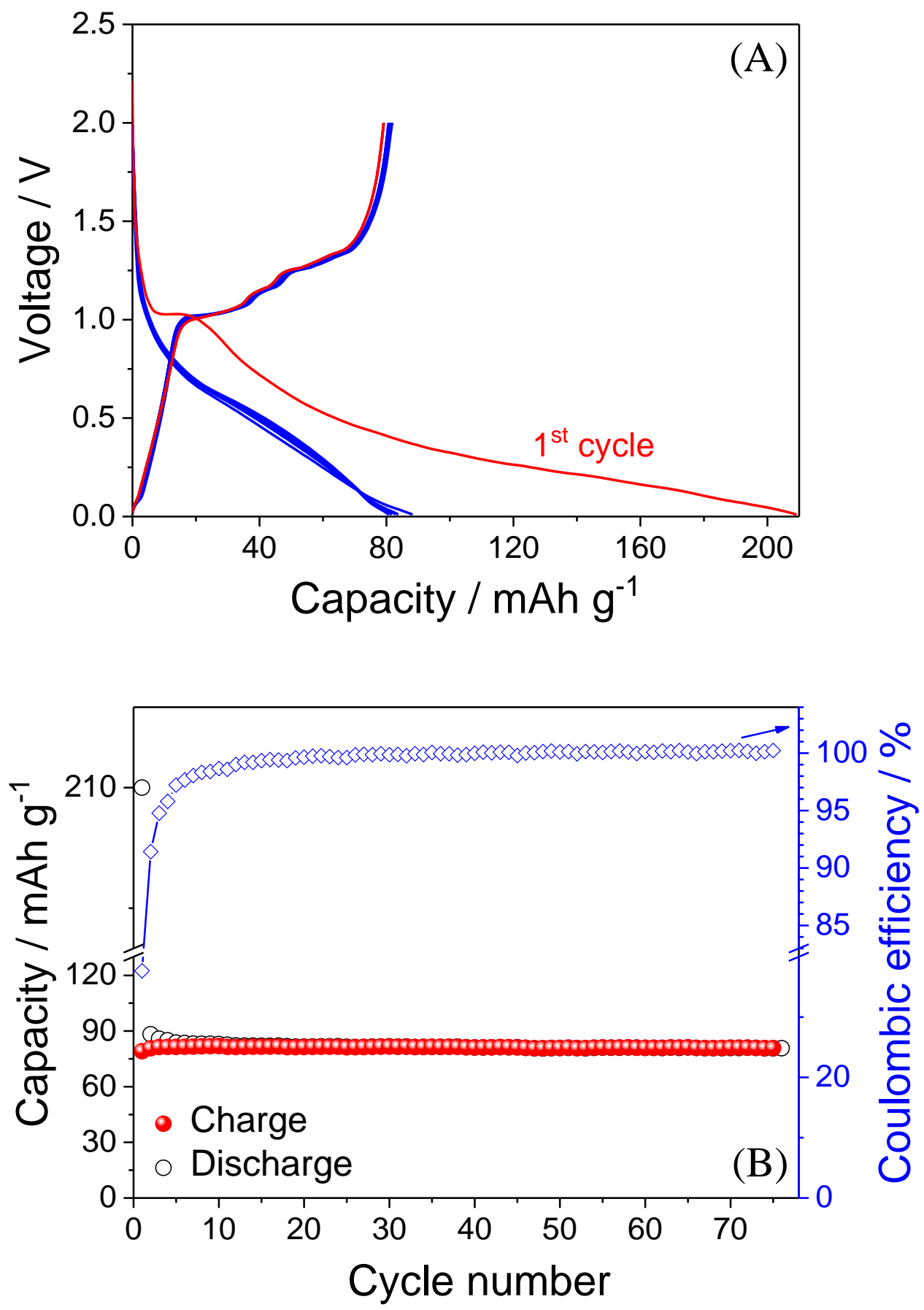

Figure 3 

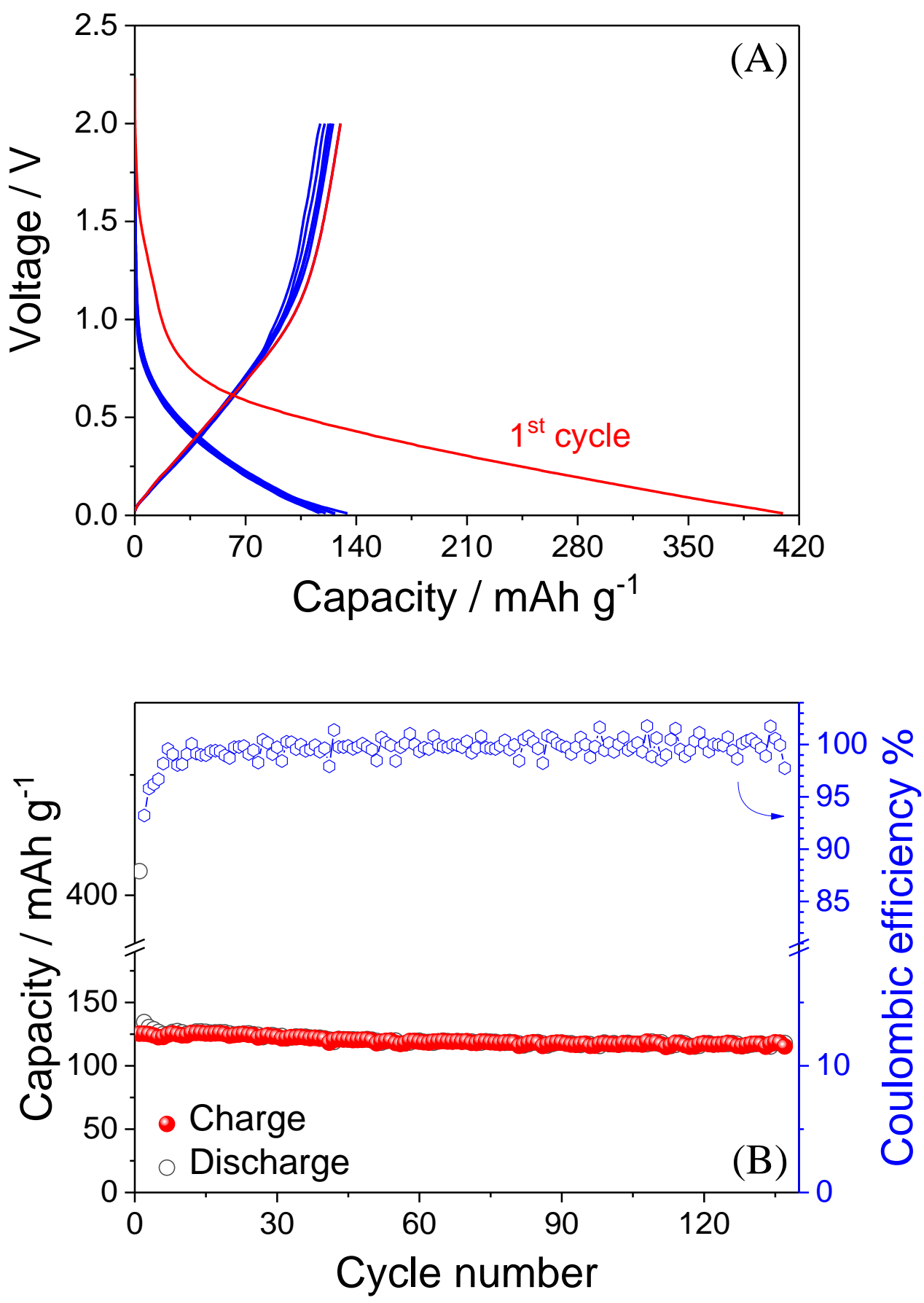

Figure 4 

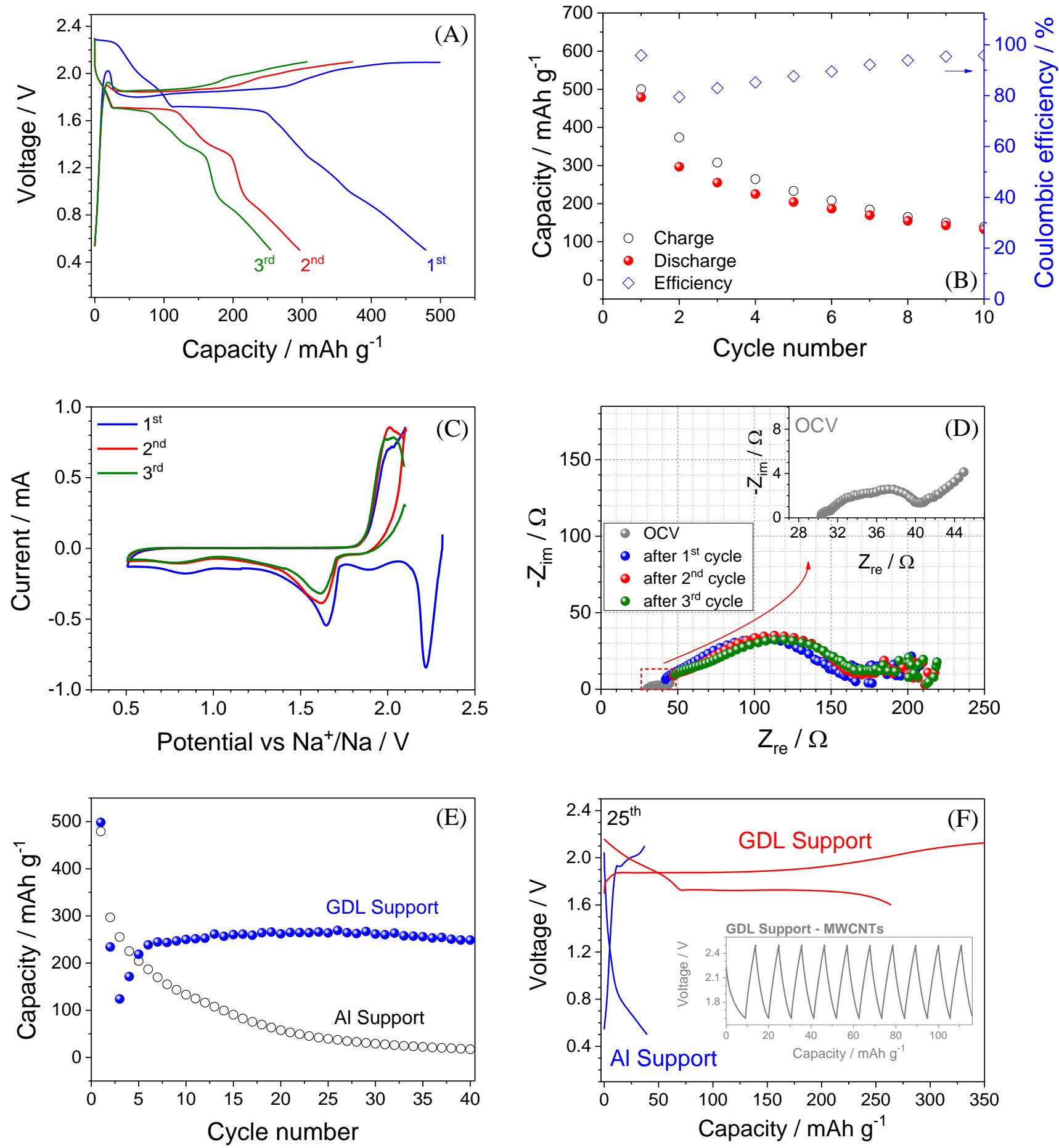

Figure 5 


\section{Table of content}

A versatile solution! Lowly flammable electrolyte solution based on triglyme shows very promising electrochemical properties for application in new-generation $\mathrm{Na}$-ion and $\mathrm{Na}-\mathrm{S}$ cells. The electrochemical study indicates fast ion transport, suitable stability, and remarkably low resistance at the electrode interphase. The applicability is demonstrated by tests in Na cells using graphite and tin-carbon anodes, as well as sulfur-multiwalled carbon nanotube cathode.

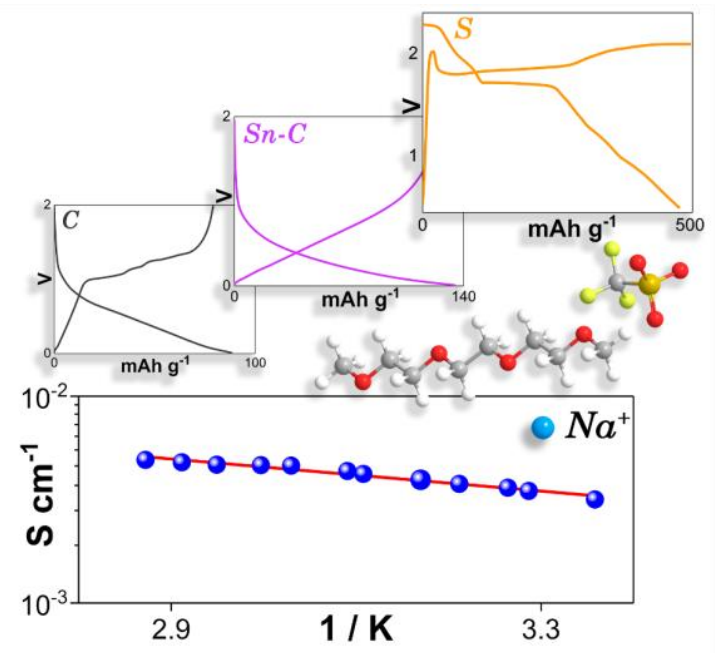

